NBER WORKING PAPER SERIES

\title{
A SIMPLE MODEL OF TRADE, CAPITAL MOBILITY, AND THE ENVIRONMENT
}

Brian R. Copeland

M. Scott Taylor

Working Paper 5898

\section{NATIONAL BUREAU OF ECONOMIC RESEARCH}

1050 Massachusetts Avenue

Cambridge, MA 02138

January 1997

An earlier version of this paper was given at the Canadian Resource and Environmental Economics Conference in Montreal, and at the Chinese University of Hong Kong. We thank participants for their comments. Financial support from SSHRC, the Killam Trusts, and the Canadian Institute for Advanced Research is gratefully acknowledged. This paper is part of NBER's research program in International Trade and Investment. Any opinions expressed are those of the authors and not those of the National Bureau of Economic Research.

(C) 1997 by Brian R. Copeland and M. Scott Taylor. All rights reserved. Short sections of text, not to exceed two paragraphs, may be quoted without explicit permission provided that full credit, including $(\mathcal{C}$ notice, is given to the source. 
A Simple Model of Trade, Capital Mobility, and the Environment

Brian R. Copeland and M. Scott Taylor

NBER Working Paper No. 5898

January 1997

International Trade and Investment

\section{ABSTRACT}

This paper examines the interaction between relative factor abundance and income-induced policy differences in determining the pattern of trade and the effect of trade liberalization on pollution. If a rich and capital abundant North trades with a poor and labor abundant South, then free trade lowers world pollution. Trade shifts the production of pollution intensive industries to the capital abundant North despite its stricter pollution regulations. Pollution levels rise in the North while those in the South fall. These results can be reversed however if the North-South income gap is "too large" for, in this case, the pattern of trade is driven by income-induced pollution policy differences across countries. Capital mobility may raise or lower world pollution depending on the pattern of trade.

Brian R. Copeland

Department of Economics University of British Columbia Vancouver, BC V6T 1Z1

CANADA copeland@econ.ubc.ca
M. Scott Taylor Department of Economics University of British Columbia Vancouver, BC V6T 1ZI CANADA and NBER taylor@econ.ubc.ca 


\section{Introduction}

There is still much that we do not know about the effects of trade liberalization on environmental quality. Grossman and Krueger (1993) have argued that NAFTA may reduce pollution in part because it will raise incomes in Mexico and thereby create a demand for better enforcement of pollution regulations. On the other hand, there is some evidence that low-income countries with relatively weak pollution regulations are developing a comparative advantage in pollution-intensive industries (Low and Yeats, 1992). In general, we would expect that trade liberalization may sometimes benefit the environment and sometimes harm it. It is therefore important that we develop a set of analytical techniques that can help us to indentify cases in which the environment may be jeopardized by trade .

In our earlier work (Copeland and Taylor, 1994, 1995), we developed a simple model to isolate the role of income differences between countries in determining the pattern of trade and the international incidence of pollution. Because the demand for environmental quality is a normal good, that model predicted that higher income countries would choose stricter pollution regulations. If there were no other differences between countries, then higher income countries would endogenously develop a comparative advantage in relative clean goods, while lower income countries would develop a comparative advantage in pollution-intensive goods. Because trade shifted the location of the most pollution intensive industries to countries with the weakest pollution regulations, the model predicts that trade liberalization could increase world pollution.

Income differences are only one of many differences between countries that contribute to the pattern of trade. Richer countries tend to be more capital abundant than poorer countries and this capital abundance in itself is an important determinant of trade patterns. Differences in factor abundance interact with income-induced differences in pollution policy to determine the pattern of trade and the effects of trade on 
environmental quality. The purpose of this paper is to develop a very simple model to examine this interaction. 1

We consider a two good model in which each industry pollutes. There are two primary factors: capital and labour. Labour is the only primary input in industry $\mathrm{X}$, while capital is the only primary input in industry $Y$. We assume that the capital-using industry is pollution-intensive, and we assume that the North is richer than the South.

Using this framework, we obtain several interesting results. First, we find that for small differences in income levels, the pattern of trade is determined by differences in the abundance of primary factors. Despite being richer, the capital abundant country exports the pollution-intensive good. Although each country chooses different pollution policy to reflect differences in income, the differences in pollution policy are not strong enough to offset the effects of differences in relative factor abundance.

Next, for differences in income that are large relative to differences in factor abundance, we find that income differences determine the pattern of trade. Higher income countries choose stricter pollution policy and if the income differences are large enough, then the higher income country will import the capital-using good, despite being a capital abundant country.

Third, the effects of trade on the incidence and level of world pollution depend on differences in factor abundance relative to differences in income levels. If factor abundance differences are large, then pollution rises in the North and falls in the South with trade. Moreover, because trade tends to shift production of pollution intensive industries to the region with stricter pollution regulations, then trade causes a decline in world pollution. This contrasts with our previous results, but is consistent with the evidence that rich countries tend to be large polluters.

On the other hand, if income differences are large, then the pattern of trade and effects of trade on pollution are consistent with our earlier results: pollution rises in the

1 Rauscher (1991) has examined the effects of capital mobility on the environment, but he has a one-good model with no goods trade. He also does not highlight the role of income in determining pollution policy. A recent working paper by Richelle (1996) also adopts a specific factors model, although different from ours, to examine the interaction between trade and capital mobility when pollution is transboundary. 
South, and falls in the North; and world pollution rises with the shift in pollutionintensive industry to the relatively low income region.

Finally, we consider the effects of capital mobility on pollution. We find that when factor abundance determines trade patterns, then allowing free capital mobility will cause world pollution to rise (from free trade levels) as pollution intensive production shifts to the South. If instead income differences determine trade patterns, then allowing free capital mobility leads to a fall in world pollution.

The next section sets up the model. Autarky is examined in section 3. The pattern of trade and the effects of trade on the environment are analyzed in section 4 . Section 5 considers capital mobility and the final section sums up.

\section{The Model}

There are two industries, $\mathrm{X}$ and $\mathrm{Y}$. Each uses a specific factor: labour for $\mathrm{X}$, and capital for Y; and each generates pollution. As shown in Copeland and Taylor (1994) we can equivalently treat pollution as if it were an input into production that can be varied to minimize costs. To keep the model simple, we adopt the following functional form:

$$
X=F\left(L, Z_{X}\right)=\left\{\begin{array}{cc}
L^{1-\alpha} Z_{X} \alpha \quad \text { if } Z_{X} / L \leq \lambda, \\
0 \quad \text { if } Z_{X} / L>\lambda,
\end{array}\right.
$$

where $\mathrm{Z}$ denotes pollution and $0<\alpha<1$. The extra constraint arises because pollution is in fact a by-product of production, and hence output must be bounded above for any given labour input. This constraint is reflected in the requirement $Z_{X} \leq \lambda L$ since this ensures that $X \leq \lambda^{\alpha} L$. Similarly, the production function for $Y$ is

$$
Y=G\left(K, Z_{y}\right)=\left\{\begin{array}{cc}
K^{1-\beta} Z_{y} \beta & \text { if } Z_{y} / K \leq \lambda, \\
0 & \text { if } Z_{y} / K>\lambda
\end{array}\right.
$$

We assume that the capital intensive industry is pollution-intensive; hence $\beta>\alpha$. We also assume that pollution is generated only by production, and that its effects are confined to the country of origin. Thus total pollution is 


$$
Z=Z_{x}+Z_{y} .
$$

Note that if the government chooses an aggregate target for pollution (so that $Z \leq \bar{Z}$ ) and if the right to pollute is distributed efficiently across firms, then we have a simple specific factors model with environmental services (pollution) as the mobile factor, and capital and labour as the specific factors.

Preferences are given by

$$
U(x, y, z)=\ln \left[x^{b} y 1-b\right]-\gamma Z
$$

where $\mathrm{b}$ is the share of spending on good $\mathrm{X}$. The indirect utility function has the form:

$$
\mathrm{V}=\ln (\mathrm{I})-\ln [\mathrm{h}(\mathrm{p})]-\gamma \mathrm{Z},
$$

where $h(p)$ is a price index, $I$ is income and $p$ is the relative price of $X$.

As in Copeland and Taylor (1994), governments choose pollution levels to maximize the utility of the representative agent, but they do not attempt to use pollution policy to manipulate the terms of trade. Choosing $Z$ to maximize (4) (treating goods prices as given) yields

$$
\tau=-\mathrm{V}_{\mathrm{Z}} / \mathrm{V}_{\mathrm{I}}=\gamma \mathrm{I} .
$$

where $\tau$ is the shadow price of the right to pollute. We assume that the government implements its policy efficiently; this is equivalent to assuming that it issues $Z$ pollution permits, with $\tau$ being the equilibrium price of a permit. Equation (5) requires that the

government choose the pollution level so that the price of a permit is equal to the marginal damage $\left(-V_{Z} / V_{I}\right)$ caused by pollution. Since environmental quality is a normal good, the marginal damage from pollution is increasing in income, and in our simple specification, marginal damage increases in direct proportion to income.

\section{Autarky}

Pollution is determined by demand and supply. The supply of pollution is determined by government policy (5). In autarky, the demand for pollution is derived from producer and consumer behaviour. From (1), the share of pollution in production costs in $X$ is fixed at $\alpha$, and hence we have $\tau Z_{X}=\alpha p_{X} X$, or 


$$
\mathrm{Z}_{\mathrm{X}}=\frac{\alpha \mathrm{p}_{\mathrm{x}} \mathrm{x}}{\tau}
$$

Similarly, pollution from the $\mathrm{Y}$ industry is

$$
\mathrm{Z}_{\mathrm{y}}=\frac{\beta \mathrm{p}_{\mathrm{y}} \mathrm{y}}{\tau} .
$$

We can eliminate outputs from (6) and (7) by noting that in autarky, the supply of $\mathrm{X}$ is equal to the demand for $X$, which is just $x=b I / p_{X}$. Similarly, $y=(1-b) I / p_{y}$. Substituting into (6) and (7) and summing, we have the total derived demand for pollution:

$$
\mathrm{Z}=\frac{(\alpha \mathrm{b}+\beta(1-\mathrm{b})) \mathrm{I}}{\tau}=\frac{\delta \mathrm{I}}{\tau},
$$

where $\delta \equiv \alpha b+\beta(1-b)$. Note that the demand for pollution is increasing in income (in autarky, a higher consumption level requires higher production, which in turn generates an increased demand for pollution). Also, the demand for pollution is decreasing in the price of pollution permits: as $\tau$ rises, firms switch to less pollution intensive techniques, and consumers substitute towards the cleaner good (since it becomes relatively cheaper).

The autarky pollution level is obtained by equating the demand for pollution (8) equal to the supply (5). This yields:

$$
\mathrm{Z}_{\mathrm{a}}=\frac{\delta}{\gamma}
$$

As in Copeland and Taylor (1994), the level of pollution in autarky is independent of the country's income. A higher income country has a larger scale of production, and hence higher pollution demand, but it also has a higher demand for environmental quality and enforces cleaner production techniques by imposing higher pollution taxes. In this model, the scale and technique effects of an increase in income on pollution just offset each other.

\section{Trade}

Let us now consider the effects of international trade. There are two potential motives for trade: capital/labour ratios may differ across countries, and pollution regulations may differ. We begin by finding the relative demand and supply for $\mathrm{X}$ to 
illustrate the effects of differences in endowments and policy on the autarky relative price of $\mathrm{X}$. Once the pattern of trade is determined, we will then consider the effects of trade on environmental quality.

Let good $Y$ be the numeraire $\left(p_{y}=1\right)$ and let $p \equiv p_{x}$. Since the share of spending on $\mathrm{X}$ is $\mathrm{b}$, the demand for $\mathrm{X}$ relative to $\mathrm{Y}$ is given by

$$
\frac{x}{y}=\frac{b}{(1-b) p} \text {. }
$$

Note that the relative demand is independent of income and hence each country's relative demand and the world relative demand all look the same.

To determine the relative supply of $\mathrm{X}$ in autarky we use the production functions (1) and (2), noting that each specific factor is fully employed in its respective sector, and that pollution in each sector is given by (6) and (7). Substituting (6) and (7) into (1) and (2), solving for outputs and dividing yields

$$
\frac{X}{Y}=\frac{(\alpha p)^{\alpha / 1-\alpha} L}{\beta^{\beta / 1-\beta_{K}}} \tau^{(\beta-\alpha) /(1-\beta)(1-\alpha)},
$$

The relative demand and supply curves for X/Y are sketched in Figure 1.

Although $\tau$ is an endogenous variable, equation (11) is nevertheless useful to help build our intuition about the patterns of trade. Let us first suppose that pollution taxes are identical across countries, but that one country (North) is more capital abundant. Since capital is used in the $\mathrm{Y}$ industry, this reduces the relative supply of $\mathrm{X}$ in the North, shifting in the relative supply curve and pushing up the autarky relative prices of $\mathrm{X}$. North has a comparative advantage in $\mathrm{Y}$, and the pattern of trade will be determined by factor endowment ratios: the capital abundant country exports the capital intensive good. This is the standard Heckscher-Ohlin story.

If instead factor abundance ratios are identical across countries, but North has a higher pollution tax, then since $\mathrm{X}$ is relatively clean, North's relative supply for $\mathrm{X}$ will shift out to the right, generating a comparative advantage in $\mathrm{X}$ based on differences in pollution policy. For identical factor endowment ratios, the country with stricter pollution policy exports the clean good. Since from (5), pollution policy is determined by income, then the trade pattern in this case is determined by income levels: North exports 
the clean good and South exports the dirty good. This was the trade pattern in our earlier papers (Copeland and Taylor 1994, 1995).

In the present paper, we assume that North is both capital abundant and rich. Capital abundance shifts the relative supply curve in to the left, while high income shifts the curve out and to the right. North's comparative advantage will be determined by the relative strength of these two effects. To obtain a condition on pollution taxes that determines the pattern of trade, note that because relative demands are identical across countries, North will export $\mathrm{X}$ if its relative supply curve is to the right of South's. Using (11) and its Southern analogue, we find that $\mathrm{X} / \mathrm{Y}>\mathrm{X}^{*} / \mathrm{Y}^{*}$ for given $\mathrm{p}$ if and only if

$$
\frac{\tau}{\tau^{*}}>\left(\frac{L^{*} / K^{*}}{L / K}\right)^{(1-\beta)(1-\alpha) /(\beta-\alpha)}
$$

Recalling that $\beta>\alpha$, then as we discussed above, (12) implies that if factor endowment ratios $(\mathrm{L} / \mathrm{K})$ are identical across countries, then North will always export $\mathrm{X}$ if it is richer (since then $\tau>\tau^{*}$ ). On the other hand, if the countries do not differ too much in aggregate income, but if Home is sufficiently capital abundant, then Home may import X and export the pollution intensive good, despite its higher pollution tax. This is because the price of $\mathrm{Y}$ depends on both the pollution tax $\tau$, and on the cost of capital. A low capital cost may more than offset high pollution taxes and result in North being an exporter of the pollution intensive good.

Equation (12) tells only part of the story about the pattern of trade because pollution taxes are endogenous. Let us now determine the equilibrium conditions for free trade. It is useful to write these in terms of production shares. Let $\theta \equiv \mathrm{px} / \mathrm{I}$ denote the share of $x$ production in national income. The for any $p$, we have from (7):

$$
\mathrm{Z}_{\mathrm{X}}=\frac{\alpha \mathrm{px}}{\tau}=\frac{\alpha \mathrm{px}}{\gamma \mathrm{I}}=\frac{\alpha \theta}{\gamma},
$$

Similarly,

$$
\mathrm{Z}_{\mathrm{y}}=\frac{\beta(1-\theta)}{\gamma}
$$


In autarky, the share of spending on $\mathrm{x}$ is the same as the share of $\mathrm{x}$ output in national income, and hence $\theta_{a}=b$. Once a country is opened up to trade, $\theta$ and $b$ may differ. Because the share of world spending on $X$ is given by $b$ we must always have

$$
\frac{\mathrm{p}\left(\mathrm{x}+\mathrm{x}^{*}\right)}{\mathrm{p}\left(\mathrm{x}+\mathrm{x}^{*}\right)+\left(\mathrm{y}+\mathrm{y}^{*}\right)}=\mathrm{b} \text {, }
$$

or

$$
\theta \varphi+\theta^{*}(1-\varphi)=b
$$

where $\varphi \equiv \mathrm{I} /\left(\mathrm{I}+\mathrm{I}^{*}\right)$ is North's share of world income and $0<\varphi<1$. Thus in free trade, if production patterns differ across countries, $b$ must lie between $\theta$ and $\theta^{*}$. Consequently, trade will typically cause $\theta$ to rise in one country and fall in the other. Moreover, note that if $\theta>\theta^{*}$, then Home must export $X$, because preferences are identical and homothetic.

To determine equilibrium production shares, note that equilibrium in world markets requires that world relative demand equal relative supply; that is, recalling the form of the relative demand (10), we require:

$$
\frac{x+x^{*}}{y+y^{*}}=\frac{b}{(1-b) p} \text {. }
$$

Using (13) and (14) in (1) and (2), and subsituting into (15) yields:

$$
\mathrm{p}=\frac{(\beta / \gamma)^{\beta}}{(\alpha / \gamma)} \frac{\mathrm{b}\left[(1-\theta){ }^{\beta} \mathrm{K}^{1-\beta}+\left(1-\theta^{*}\right) \mathrm{K}^{* 1-\beta}\right]}{(1-\mathrm{b})\left[\theta^{\alpha} \mathrm{L}^{1-\alpha}+\theta^{*} \mathrm{~L}^{* 1-\alpha}\right]} .
$$

As well, relative supply in each country must also be equal to the world relative price. In the North, we have

$$
p=\frac{(\beta / \gamma)^{\beta} K^{1-\beta}}{(\alpha / \gamma)^{\alpha} L^{1-\alpha}} \frac{\theta^{1-\alpha}}{(1-\theta)^{1-\beta}} .
$$

We can now obtain two simple equations that determine the two endogenous variables $\theta$ and $\theta^{*}$. Because each country faces the same goods prices in free trade, equating (17) and its Southern analogue yields

$$
\frac{\mathrm{K}^{1-\beta}}{\mathrm{L}^{1-\alpha}} \frac{\theta^{1-\alpha}}{(1-\theta)^{1-\beta}}=\frac{\mathrm{K}^{* 1-\beta}}{\mathrm{L}^{* 1-\alpha}} \frac{\theta^{* 1-\alpha}}{\left(1-\theta^{*}\right)^{1-\beta}} .
$$


Next relative supply conditions in each country must reflect world relative demand. Equating (16) and (17) yields

$$
\frac{\mathrm{K}^{1-\beta}}{\mathrm{L}^{1-\alpha}} \frac{\theta^{1-\alpha}}{(1-\theta)^{1-\beta}}=\frac{\mathrm{b}\left[(1-\theta)^{\beta} \mathrm{K}^{1-\beta}+\left(1-\theta^{*}\right) \mathrm{K}^{* 1-\beta}\right]}{(1-\mathrm{b})\left[\theta^{\alpha} \mathrm{L}^{1-\alpha}+\theta^{*} \mathrm{~L}^{* 1-\alpha}\right]} .
$$

Figure 2 plots (18) and (19) for the case where Home is an exporter of the clean good. Equation (18) yields an upward sloping relation between $\theta$ and $\theta^{*}$ because a higher relative price of $\mathrm{X}$ must lead to higher production of $\mathrm{X}$ in both countries. The curvature depends on relative factor endowments. Equation (19) reflects world supply and demand, and yields a negative relationship between $\theta$ and $\theta^{*}$. For a given level of world demand for $\mathrm{X}$, if more is produced at Home ( $\theta$ rises) then less must be produced abroad so that markets clear $\left(\theta^{*}\right)$ falls.

We can use (18) to determine the effects of factor endowments on production patterns. Let the labour/capital ratio in each country be denoted by $\lambda$ and $\lambda^{*}$, respectively. Then (18) can be written as

$$
\frac{\left(\theta / \theta^{*}\right)^{1-\alpha}}{\left[(1-\theta) /\left(1-\theta^{*}\right)\right]^{1-\beta}}=\frac{\left(\mathrm{K} / \mathrm{K}^{*}\right)^{\beta-\alpha}}{\left(\lambda^{*} / \lambda\right)^{1-\alpha}} .
$$

To interpret (20), first suppose that the two countries are identical. Then with $\mathrm{K}=\mathrm{K}^{*}$ and $\lambda=\lambda^{*}$, we must have identical production patterns: $\theta=\theta^{*}$. Next suppose that factor endowment ratios are identical $\left(\lambda=\lambda^{*}\right)$, but that North is richer than the South $\left(K>K^{*}\right)$. Then we have $\theta>\theta^{*}$ : North allocates a larger fraction of its economy to $\mathrm{X}$ production than the South. This is because with North's higher wealth, it chooses stricter pollution regulations, which favours the relatively clean industry. In this case, North exports the clean good.

However, suppose that North is relatively well endowed with capital $\left(\lambda<\lambda^{*}\right)$. Then providing that $K$ is not too large, we have $\theta<\theta^{*}$. Despite its higher income, North may export the dirty good because its abundance of capital more than offsets the costlier pollution regulations. Finally, note from (20) that for any given $\lambda$ and $\lambda^{*}$, if North is sufficiently rich ( $\mathrm{K}$ is sufficiently large), then we must have $\theta>\theta^{*}$. 
Proposition 1. Suppose $\mathrm{L}^{*} / \mathrm{K}^{*}$ and $\mathrm{L} / \mathrm{K}$ are given and North is relatively capital abundant. Then there exists $\overline{\mathrm{K}}$ such that (1) if $\mathrm{K}<\overline{\mathrm{K}}$ then North exports the dirty good, and if $\mathrm{K}>\overline{\mathrm{K}}$ then North exports the clean good.

Next, let us consider the effects of trade on pollution. Total pollution is given by

$$
Z=Z_{x}+Z_{y}=\frac{\alpha \theta+\beta(1-\theta)}{\gamma}=\frac{\beta-(\beta-\alpha) \theta}{\gamma}
$$

From (21), we have $d Z / d \theta<0$. Thus if the share of the clean good $(X)$ in national income rises with trade, then pollution falls, and if the share of the dirty good rises ( $\theta$ falls), then pollution rises.

Proposition 2. Consider a movement from autarky to free trade. If North exports the clean good, then pollution falls in the North and rises in the South. If North exports the dirty good, then pollution rises in the North and falls in the South.

Proof: Use (21) and Prop. 1.

Propositions 1 and 2 generalize our earlier work by allowing a richer interaction between income levels and comparative advantage. In Copeland and Taylor (1994), trade always lowered pollution in the North by encouraging pollution intensive industries to move to low income countries. In the present model, comparative advantage is determined by the interaction between capital abundance and income. A high income country which is also capital abundant may have a comparative advantage in pollution intensive industries, and may therefore choose to allow pollution to rise with trade. However, our results also suggest that a sufficiently high income can push up environmental regulations by enough to more than offset the cost advantage due to capital abundance. Sufficiently rich capital abundant countries will reduce their pollution and export clean goods in the move to free trade.

Proposition 2 indicates that trade alters the incidence of pollution across countries by stimulating pollution intensive industries in some countries and stimulating clean industries in other countries. It is also of interest to determine whether trade leads to a 
net increase or decrease in global pollution. Using (9), world pollution in autarky is given by

$$
\mathrm{Z}_{\mathrm{a}}^{\mathrm{w}}=2 \delta / \gamma
$$

Using (21), world pollution in free trade is given by

$$
\mathrm{Z}_{\mathrm{t}}^{\mathrm{W}}=\mathrm{Z}+\mathrm{Z}^{*}=\frac{2 \beta-(\beta-\alpha)\left(\theta+\theta^{*}\right)}{\gamma}
$$

Subtracting (22) from (23) yields

$$
Z_{t}^{W}-Z_{a}^{W}=(\beta-\alpha)\left(\theta-\theta^{*}\right)\left(\varphi-\frac{1}{2}\right)
$$

where it should be recalled that $\varphi$ is North's share of world income. Now, we have $\beta>\alpha$ since $\mathrm{Y}$ is pollution intensive, and we have $\varphi>1 / 2$ since North is richer than South by assumption. Thus the sign of (24) depends on the sign of $\theta-\theta^{*}$. If North exports the clean $\operatorname{good}\left(\theta>\theta^{*}\right)$, then world pollution rises with trade. This is the same result obtained in Copeland and Taylor (1994). Because $\tau>\tau^{*}$, a shift of pollution intensive industries to the South raises the average pollution intensity of global production and raises world pollution. This is the basis of the argument that trade may create pollution havens that lower average global environmental quality.

Once we allow for differences in factor endowments, however, a richer set of possibilities emerges. If the North is capital abundant, then it may export the pollution intensive good. In this case, $\theta<\theta^{*}$, and from (24), world pollution falls with trade. In this case, trade shifts some of the pollution intensive industry to the North, where stricter pollution regulations lead to cleaner techniques of production. As a result, trade liberalization can lower world pollution.

Proposition 3. Consider a movement from autarky to free trade. If North exports the clean good, then world pollution rises with trade. If North exports the dirty good, then world pollution falls with trade.

\section{Capital mobility}


Suppose both countries produce both goods in free trade. Then free entry will ensure that profits are zero. Hence we must have:

$$
\begin{array}{ll}
\mathrm{c}_{\mathrm{X}}(\mathrm{w}, \tau)=\mathrm{p}, & \mathrm{c}_{\mathbf{X}}\left(\mathrm{w}^{*}, \tau^{*}\right)=\mathrm{p}, \\
\mathrm{cy}_{\mathrm{y}}(\mathrm{r}, \tau)=1, & \mathrm{c}_{\mathrm{y}}\left(\mathrm{r}^{*}, \tau *\right)=1,
\end{array}
$$

where $c_{x}$ and $c_{y}$ are the unit cost functions, and where $p$ is the same across countries in free trade. Since North is richer, we must have $\tau>\tau^{*}$. Thus from (26), the return on capital is lower in the North than the South because of the stricter pollution regulations.

Now suppose we allow capital to move freely. Then capital will flow from North to South. Depending on parameters, it is possible for all capital to leave the North and move to the South. However, suppose that the return on capital is equalized across countries before this happens. From (26), note that if $r=r^{*}$, then we must have $\tau=\tau^{*}$, and consequently, $w=w^{*}$. Thus free trade, combined with mobile capital will equalize factor prices, provided both industries remain active in each country.

Let us now consider the effect of capital mobility on world pollution. Using (6) and (7), world pollution is

$$
Z^{W}=Z+Z^{*}=\frac{\alpha\left[p\left(x+x^{*}\right)+\beta\left(y+y^{*}\right)\right.}{\tau} .
$$

From our assumptions on preferences, a fraction b of world income is spent on good X; hence we have $p\left(x+x^{*}\right)=b\left(I+I^{*}\right)$, where $I$ and $I^{*}$ denote national incomes, inclusive of payments and receipts for income from foreign-owned capital. Thus (27) can be written as

$$
\mathrm{Z}^{\mathrm{W}}=\frac{\alpha \mathrm{b}\left(\mathrm{I}+\mathrm{I}^{*}\right)+\beta(1-\mathrm{b})\left(\mathrm{I}+\mathrm{I}^{*}\right)}{\tau}=\frac{2[\alpha \mathrm{b}+\beta(1-\mathrm{b})]}{\gamma}=\frac{2 \delta}{\gamma} .
$$

where the middle step follows since $\tau=\tau^{*}=\gamma \mathrm{I}=\gamma \mathrm{I}^{*}$. As in Copeland and Taylor (1994), factor price equalization also equalizes incomes across countries: the richer country chooses to reduce its income in return for a cleaner environment, while the poorer country prefers to allow its environment to deteriorate in return for a higher income. If the countries are not too different at the outset, then this process will fully equalize incomes and factor prices. 
Comparing (26) with (22), we see that world pollution with both free trade and mobile capital is the same as autarky world pollution. Since we have already compared free trade pollution levels with autarky pollution levels in Proposition 3, it is straightforward to determine the effects of capital mobility on world pollution.

Proposition 4. Consider a world that initially has free trade in goods, but not factors. Now suppose that capital is allowed to flow freely between countries, and suppose that both industries remain active in each country. Then (a) if North initially exports the clean good, world pollution will fall when capital is allowed to move; and (b) if North initially exports the dirty good, then world pollution will rise when capital is allowed to move.

\section{Conclusion}

In our earlier work, we developed a model in which countries differed only in income levels. The purpose of that work was to isolate the role of income effects and identify the influences that differences in income might have on the polluting effects of trade. In reality, trade is determined by the complex interaction of many different forces. In this paper, we illustrate the interaction between the effects of factor endowment differences with income effects.

Our results depend on the relative strength of the two forces. If income effects dominate, then the results are much the same as before: trade can lead to the creation of pollution havens in poor countries and trade can increase world pollution. However, if differences in factor endowment ratios dominate, then richer countries may be net exporters of pollution intensive goods and trade may reduce world pollution.

Capital mobility may raise or lower world pollution. However, in the case where North initially exports the pollution intensive good, increased capital mobility may raise world pollution from its free trade level. Since this case seems to be empirically relevant during the development process, the concerns about the environmental effects of capital 
mobility expressed by Daly and Goodland (1994) and others should be given close scutiny. It should be noted however that free trade plus capital mobility leave world pollution unchanged from its autarky level. 
Figure 1. Autarky

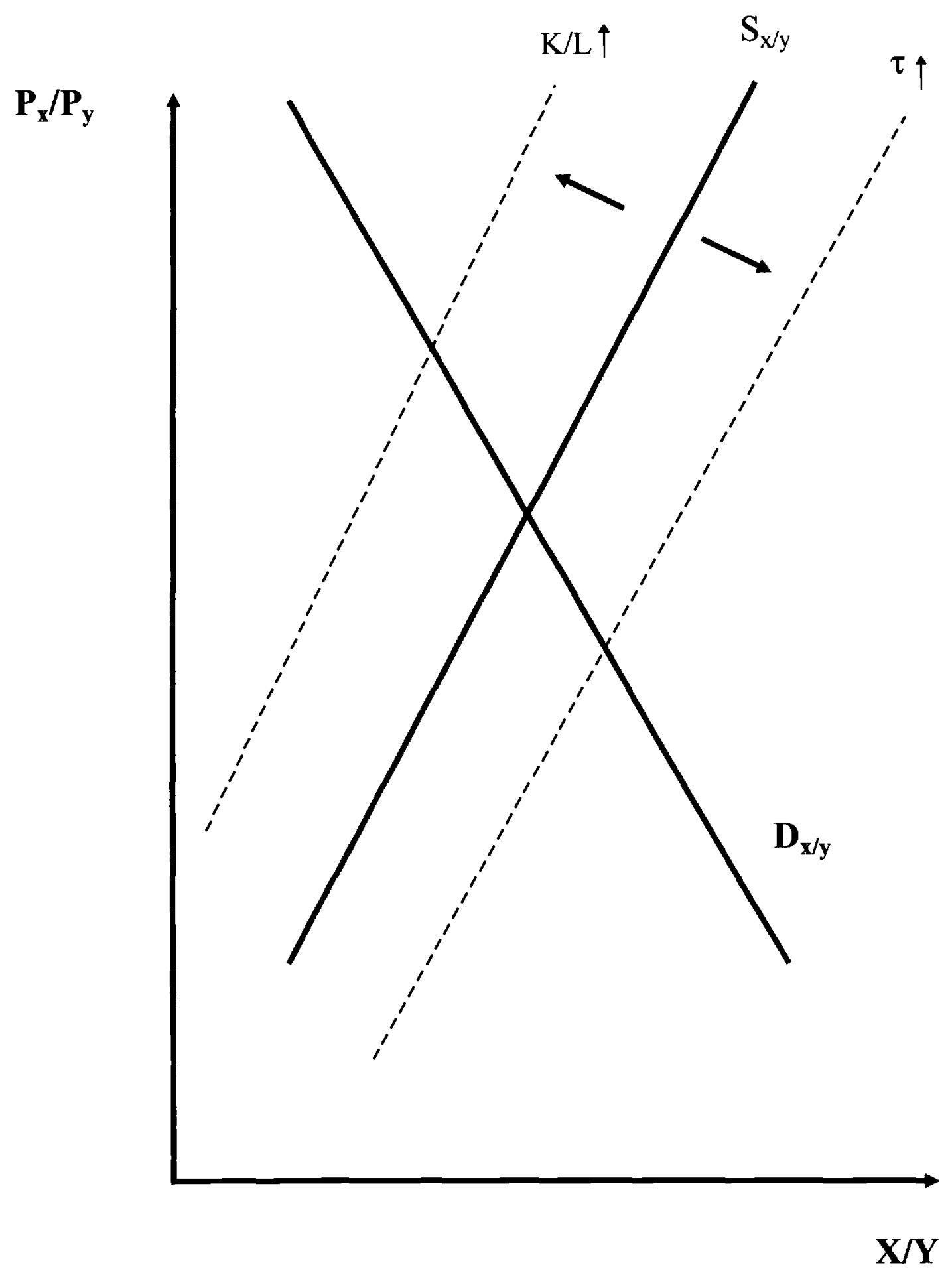


Figure 2. Free Trade

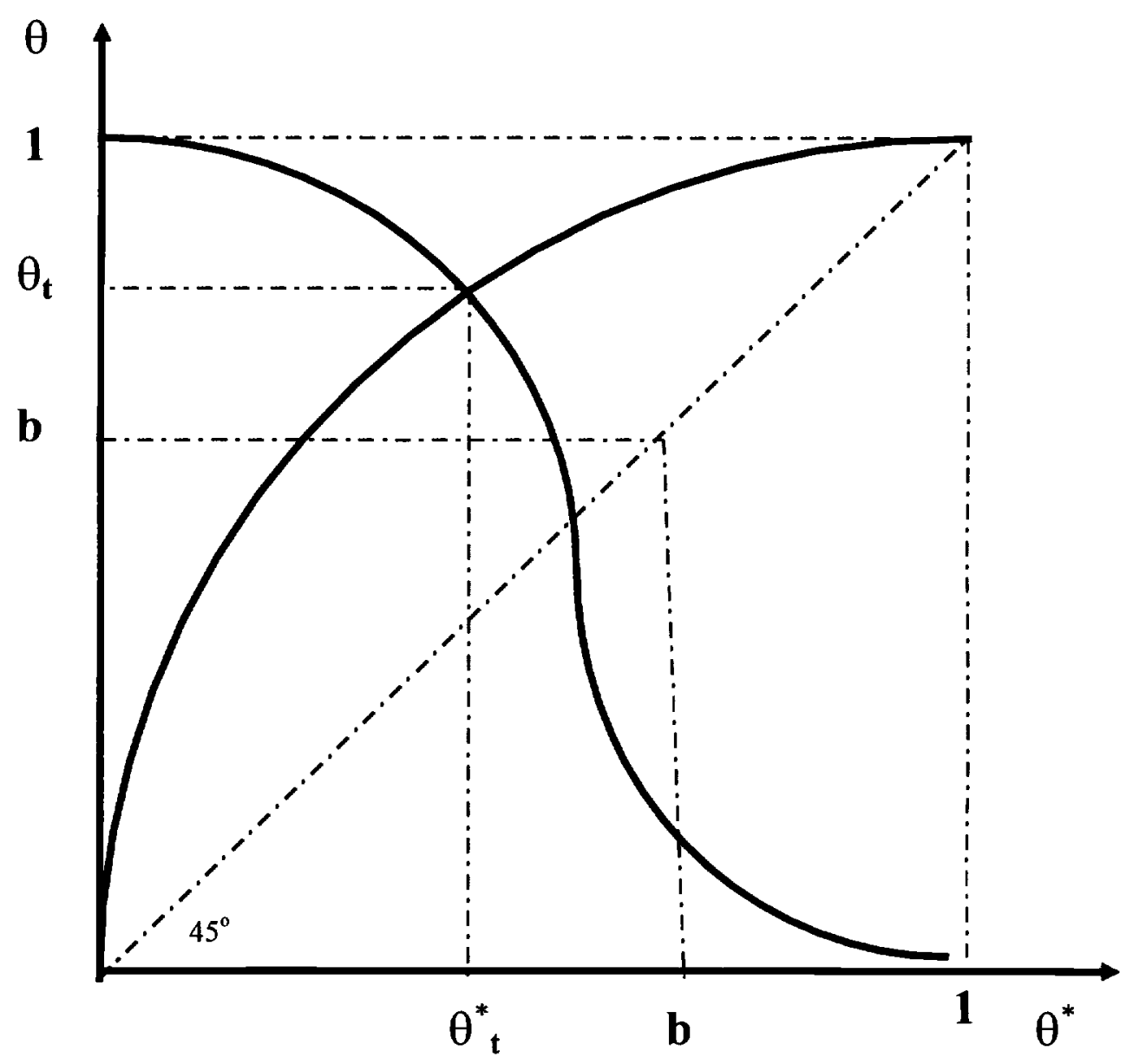




\section{References}

Copeland, B.R. and M.S. Taylor, "North-South Trade and the Environment," Quarterly Journal of Economics, 109 (1994): 755-87.

Copeland, B.R. and M.S. Taylor, "Trade and Transboundary Pollution," American Economic Review, 85 (1995a): 716-737.

Daly, H. and R. Goodland, "An ecological-economic assessment of deregulation of international commerce under GATT," Population and Environment, 15 (1994): 395 427 .

Grossman, Gene M. and Krueger, Alan B., "Environmental Impacts of a North American Free Trade Agreement." in Peter Garber, ed., The Mexico-U.S. Free Trade Agreement. Cambridge, Mass.: MIT Press, 1993.

Low, Patrick, and Alexander Yeats, "Do 'Dirty' Industries Migrate?" in Patrick Low, ed., International Trade and the Environment: World Bank Discussion Papers, (Washington, DC: World Bank, 1992).

Rauscher, M., "National environmental policies and the effects of economic integration," European Journal of Political Economy 7 (1991): 313-29.

Richelle, Y., "Trade Incidence on Transboundary Pollution: Free Trade can Benefit the Global Environmental Quality" University of Laval Discussion Paper No. 9616 (1996). 